\title{
Effect of Neem Oil Formulation on the Population of Soil Fungi and Disease Intencity of Cercospora Leaf Spot (Cercospora capsici) on Chilli Plants (Capsicum annuum)
}

\author{
Sri Hartati $^{\text {** }}$, Danar Dono ${ }^{1}$, Rika Meliansyah ${ }^{1}$, Mukhamad Agung Hidayat ${ }^{2}$ \\ ${ }^{1}$ Departement of Plant Pests and Diseases, Agriculture Faculty, Universitas Padjadjaran, Jatinangor, West Java, Indonesia, \\ 45363. \\ ${ }^{2}$ Alumnus of Departement of Plant Pests and Diseases, Agriculture Faculty, Universitas Padjadjaran, Jatinangor, West Java, \\ Indonesia, 45363. \\ * Corresponding Author: s.hartati@unpad ac.id
}

\begin{abstract}
Soil fungi and cercospora leaf spot are soil inhabitants and plant disease, respectively, that usually occur on chilli grown area. Formulation of neem oil was reported to have a role as an environmentally friendly botanical pesticide. This research was objected to studying the effect of neem oil formulation on the population of soil fungi and its suppression on cercospora leaf spot intensity of chilli crop. The field experiment was arranged in the randomized complete block design. The treatments were the concentration of neem oil formulation, i.e. $0 \%, 1 \%, 1.25 \%, 1.50 \%, 1.75 \%$, and $2.0 \%$. In vitro experiment on the suppression of neem oil formulation on the predominant soil, fungi were arranged in the completely randomized design. The results showed that neem oil formulation did not affect the soil fungi population and cercospora leaf spot intensity. However, $2.0 \%$ neem oil had the lowest soil population. Neem oil formulation at $1.75 \%$ caused the highest suppression on TMa01 isolate $(49.81 \%)$, and $1.25 \%, 1.50 \%, 1.75 \%$ and $2.0 \%$ of neem oil formulation caused more than $50 \%$ suppression on TMf01 isolate in vitro. Neem oil formulation at $2.0 \%$ caused the highest suppression on cercospora leaf spot intensity (46.34\%).
\end{abstract}

Keywords: Azadirachta indica, botanical pesticide, neem oil

\section{ABSTRAK}

\section{Pengaruh Formulasi Minyak Mimba terhadap Populasi Jamur Tanah dan Intensitas Penyakit Bercak Daun Cercospora (Cercospora capsici) pada Tanaman Cabai Merah (Capsicum annuum)}

Jamur tanah dan penyakit bercak daun cercospora merupakan jamur dan penyakit yang sering ditemukan di lahan pertanaman cabai. Formulasi minyak mimba telah dilaporkan berperan sebagai pestisida nabati yang ramah lingkungan. Penelitian ini bertujuan untuk menguji pengaruh formulasi minyak mimba terhadap populasi jamur tanah dan tingkat penekanannya terhadap intensitas penyakit bercak daun cercospora pada tanaman cabai merah. Penelitian di lapangan menggunakan Rancangan Acak Kelompok. Perlakuan yang diuji adalah formulasi minyak mimba konsentrasi $0 \%, 1 \%$, $1,25 \%, 1,50 \%, 1,75 \%$, dan 2,0\%. Pengujian tingkat penekanan formulasi minyak mimba terhadap jamur tanah yang dominan dilakukan secara in vitro menggunakan Rancangan Acak Lengkap (RAL). Hasil penelitian menunjukkan bahwa formulasi minyak mimba tidak berpengaruh terhadap populasi jamur tanah dan intensitas penyakit bercak daun cercospora. Akan tetapi, perlakuan formulasi minyak mimba dengan konsentrasi 2,0\% memiliki populasi jamur tanah terendah. Formulasi minyak mimba dengan konsentrasi $1,75 \%$ menyebabkan tingkat penekanan tertinggi terhadap isolat TMa01 sebesar 49,81\% dan konsentrasi 1,25\%, 1,50\%, 1,75\% dan 2,0\% menyebabkan penekanan lebih dari 50\% terhadap isolat TMf01 secara in vitro. Perlakuan formulasi minyak mimba konsentrasi $2,0 \%$ paling tinggi dalam menekan intensitas penyakit bercak daun cercospora yaitu sebesar $46,34 \%$.

Kata kunci: Azadirachta indica, minyak mimba, pestisida nabati

\section{PENDAHULUAN}

Jamur merupakan salah satu organisme yang dapat hidup dan berkembang di tanah. Beberapa jamur tanah dilaporkan sebagai patogen tumbuhan dan yang lainnya berperan sebagai antagonis. Populasi jamur tanah di sekitar pertanaman pada umumnya tinggi dibandingkan pada tanah tanpa pertanaman.

Tanaman cabai merupakan salah satu tanaman yang banyak diserang oleh patogen, mulai dari benih, bibit sampai buah. Beberapa penyakit pada tanaman cabai antara lain penyakit layu fusarium, bercak cercospora, dan antraknosa. Pengendalian penyakit yang umum dilakukan pada tanaman cabai adalah menggunakan pestisida kimia sintetik.

Pestisida kimia sintetik merupakan pestisida yang sering digunakan oleh petani untuk mengendalikan hama dan penyakit tanaman. Akan tetapi, penggunaan pestisida kimia sintetik dapat menyebabkan dampak negatif terhadap lingkungan. Salah satu dampak negatif dari penggunaan pestisida sintetik adalah terganggunya populasi jamur yang ada di tanah. Rendahnya populasi jamur tanah dapat disebabkan oleh adanya paparan maupun residu pestisida kimia sinetik yang terus menerus. Salah satu usaha menekan penggunaan pestisida kimia sintetik adalah dengan menggunakan pestisida nabati. Pestisida nabati pada umumnya memiliki sifat mudah terdegradasi, baik oleh cahaya matahari, suhu, air, maupun mikroba. Sifat pestisida nabati ini yang membedakannya dengan pestisida kimia sintetik.

Salah satu pestisida nabati yang dilaporkan efektif adalah mimba (Azadirachta indica). Mimba 
telah dilaporkan mampu menekan pertumbuhan beberapa jamur patogen. Pestisida nabati dari ekstrak mimba berpotensi sebagai antijamur, antibakteri, nematoda, protozoa, dan virus (Natarajan et al., 2003; Thomas et al., 2016). Locke (1990) melaporkan bahwa mimba mempunyai efek mencegah perkembangan penyakit embun tepung pada bunga lilac. Ekstrak kernel biji mimba (NEK) mampu menekan pertumbuhan empat patogen yaitu Monilinia fructicola, Penicillium expansum, Trichothecium roseum, dan Alternaria alternata pada media PDA (Wang et al., 2010).

Beberapa formulasi berbahan aktif mimba saat ini telah tersedia secara komersial, diantarannya adalah formulasi mimba 50 EC. Formulasi mimba 50 EC telah dilaporkan dapat menurunkan populasi hama utama kedelai, yaitu Aphis glycine, Nezara viridula, dan Riptortus linearis dan tidak berdampak negatif terhadap populasi musuh alaminya (Barus, 2016). Selain itu, formulasi mimba 50 EC juga dilaporkan dapat mengendalikan penyakit embun tepung pada tanaman kedelai (Meliansyah et al., 2016). Penelitian ini bertujuan untuk mengetahui pengaruh formulasi minyak mimba terhadap populasi jamur tanah dan intensitas penyakit bercak daun cercospora pada tanaman cabai.

\section{BAHAN DAN METODE}

Percobaan dilaksanakan di kebun percobaan Ciparanje dan Laboratorium Bioteknologi Proteksi Tanaman, Departemen Hama dan Penyakit Tumbuhan, Fakultas Pertanian, Universitas Padjadjaran. Penelitian dilakukan dengan mengisolasi jamur tanah, menghitung populasinya, dan menghitung intensitas penyakit bercak daun cercospora pada lahan pertanaman cabai yang telah diaplikasi formulasi minyak mimba. Tahap percobaan berikutnya menguji tingkat penekanan formulasi minyak mimba terhadap isolat jamur tanah yang dominan didapatkan secara in vitro di laboratorium. Penelitian di lapangan menggunakan Rancangan Acak Kelompok (RAK) terdiri dari 6 perlakuan dan 5 ulangan. Perlakuan yang diuji adalah formulasi minyak mimba konsentrasi $0 \%, 1 \%, 1,25 \%, 1,50 \%$, $1,75 \%$, dan 2,0\%. Penelitian di laboratorium menggunakan Rancangan Acak Lengkap (RAL).

\section{Pengambilan sampel tanah}

Frekuensi pengambilan sampel tanah selama aplikasi penyemprotan formulasi minyak mimba dilakukan sebanyak tiga kali. Pengambilan sampel tanah pertama dilakukan sebelum penyemprotan formulasi minyak mimba yaitu pada 3 minggu setelah tanam (mst). Pengambilan sampel tanah kedua dilakukan setelah penyemprotan formulasi minyak mimba aplikasi ketiga yaitu pada 6 mst. Pengambilan sampel tanah ketiga dilakukan diakhir musim tanam cabai yaitu setelah aplikasi ke-4 pada 9 mst.

Teknik pengambilan sampel tanah dilakukan dengan mengambil lima titik sampel tanah secara diagonal dari satu petak perlakuan selanjutnya dikompositkan. Sampel tanah diambil dari petak perlakuan berukuran $4 \mathrm{~m}$ x $3 \mathrm{~m}$. Sampel tanah diambil dari kedalaman $0-20 \mathrm{~cm}$. Sampel tanah yang sudah dikompositkan ditempatkan pada kantong plastik yang telah diberi label, selanjutnya dianalisis di laboratorium untuk melihat populasi jamur yang ada.

\section{mimba}

Pembuatan larutan formulasi minyak

Pembuatan larutan formulasi minyak mimba dilakukan dengan menggunakan pelarut air. Larutan formulasi minyak mimba dibuat dalam konsentrasi $0 \%, 1 \%, 1,25 \%, 1,50 \%, 1,75 \%$, dan $2,0 \%$. Larutan formulasi tersebut dibuat dengan mencampur formulasi minyak mimba dengan volume tertentu sesuai konsentrasi, selanjutnya ditambah pelarut air hingga volume $100 \mathrm{ml}$.

\section{Isolasi dan Penghitungan Populasi Jamur Tanah}

Isolasi jamur tanah dilakukan dengan menggunakan metode agar cawan atau cawan pengenceran. Prinsip dasar metode cawan pengenceran adalah tiap sel jamur yang hidup dalam suspensi tanah akan berkembang dan membentuk suatu koloni dalam kondisi lingkungan yang sesuai. Metode cawan pengenceran ini dilakukan dengan pengenceran berseri. Isolasi jamur tanah dilakukan pada sampel tanah yang telah diambil pada pengenceran $10^{-3}$.

Suspensi tanah pada seri pengenceran $10^{-3}$ diambil sebanyak $0,1 \mathrm{ml}$ selanjutnya disebarkan pada media Potato Dextrose Agar (PDA) dan Martin Agar (MA). Media PDA dan MA yang berisi suspensi tanah diinkubasi pada suhu kamar. Setelah tujuh hari inkubasi, dilakukan perhitungan jumlah koloni jamur dengan rumus sebagai berikut:

\section{Jumlah total mikroorganisme (CFU/mL) $=$ Jumlah koloni $\mathrm{x}$ Faktor pengenceran*}

$$
\text { *Faktor pengenceran }=\frac{1}{\text { Tingkat pengenceran }}
$$

Pengamatan juga dilakukan terhadap karakteristik koloni jamur yang tumbuh pada media PDA dan MA.

\section{Tingkat Penekanan Formulasi Minyak Mimba terhadap Jamur Tanah secara In Vitro}

Pengujian toksisitas minyak mimba terhadap jamur tanah secara in vitro menggunakan metode umpan beracun dengan menumbuhkan inokulum jamur pada media PDA yang sudah bercampur dengan pestisida (Sharvelle, 1979). Metode ini dilakukan dengan mencampur larutan formulasi minyak mimba sesuai konsentrasi aplikasi di lapangan yaitu $0 \%, 1 \%$, $1,25 \%, 1,50 \%, 1,75 \%$, dan 2,0\% dengan media PDA. Inokulum jamur tanah yang didapat dari hasil isolasi ditumbuhkan ditengah media PDA yang telah berisi larutan formulasi minyak mimba pada cawan petri. 
Jamur tanah yang diuji adalah isolat yang dominan dan paling cepat pertumbuhannya dalam media PDA.

Kultur jamur diinkubasi pada suhu kamar selama tujuh hari. Pengamatan metode umpan beracun dilakukan dengan mengukur diameter koloni jamur yang tumbuh (Sharvelle, 1979). Persentase penekanan jamur oleh formulasi minyak mimba dihitung dengan rumus:

$$
\mathrm{TP}=\left[\frac{\mathrm{DK}-\mathrm{DP}}{\mathrm{DK}}\right] \times 100 \%
$$

Dimana: TP: Tingkat penekanan

DK: Diameter jamur pada kontrol

DP: Diameter jamur pada perlakuan

\section{Pengamatan Intensitas Penyakit Bercak Daun Cercospora}

Pengamatan terhadap intensitas penyakit bercak daun cercospora pada tanaman cabai dilakukan setiap satu minggu sekali mulai dari 2 MST sampai panen. Pengambilan tanaman sampel dilakukan secara diagonal pada petak sampel. Jumlah tanaman sampel yang diamati adalah $10 \%$ dari 49 tanaman per petak perlakuan berukuran $4 \mathrm{~m}$ x $3 \mathrm{~m}$. Intensitas penyakit bercak daun cercospora diamati dengan mengukur keparahan penyakit (disease severity) dengan menilai proporsi bagian tanaman yang sakit dilihat dari gejala penyakitnya dalam satu individu tanaman. Keparahan penyakit dihitung dengan rumus (Twnsend dan Hauberger, 1943 dalam Unterstenhofer, 1976):

$\mathrm{I}=\frac{\mathrm{n} \times \mathrm{y}}{\mathrm{N} \times \mathrm{Y}} \times 100 \%$

Keterangan:

I : Intensitas penyakit (\%)

$\mathrm{n}$ : Jumlah tanaman sampel yang mempunyai nilai skor yang sama

$\mathrm{y}:$ Nilai skor

$\mathrm{N}$ : Jumlah total tanaman sampel yang diamati

Y: Nilai skor tertinggi yang digunakan

Skoring kategori serangan yang digunakan:

$\begin{array}{cc}0 & \text { Tidak bergejala } \\ 1 & 1 \% \leq \mathrm{x}<12,5 \% \\ 2 & 12,5 \% \leq \mathrm{x}<25 \% \\ 3 & 25 \% \leq \mathrm{x}<50 \% \\ 4 & 50 \% \leq \mathrm{x}<75 \% \\ 5 & 75 \% \leq \mathrm{x}<100 \%\end{array}$

\section{Data Penunjang}

Data penunjang dibutuhkan untuk mengetahui faktor - faktor yang berpengaruh terhadap populasi jamur tanah, intensitas serangan penyakit, dan daya tahan formulasi mimba. Data penunjang yang diamati adalah pH tanah, suhu harian, curah hujan, dan kelembapan yang didapatkan dari stasiun cuaca.

\section{HASIL DAN PEMBAHASAN}

\section{Populasi dan Karakteristik Jamur Tanah Hasil Isolasi}

Hasil isolasi jamur tanah dari lahan pertanaman cabai dengan perlakuan formulasi minyak mimba di lapangan dididapatkan 21 isolat jamur tanah. Beberapa isolat jamur tanah tersebut didapatkan dengan populasi tinggi dan isolat lainnya didapatkan dengan populasi rendah (Tabel 2). Isolat jamur tanah yang didapatkan dengan populasi koloni tertinggi adalah isolat TMf01 yaitu sebesar $63 \times 10^{4}$ $\mathrm{cfu} / \mathrm{ml}$ (Tabel 2).

Isolat jamur tanah yang didapatkan dari lahan pertanaman cabai dengan perlakuan formulasi minyak mimba di lapangan menunjukkan karakteristik koloni yang berbeda-beda (Tabel 3). Perbedaan karakteristik koloni beberapa jamur tanah yang didapatkan terlihat pada bentuk, warna, tepi, tekstur, dan strukturnya dalam lingkaran konsentris ke tepi cawan petri setelah tujuh hari inkubasi. Hasil isolasi didapatkan enam isolat jamur tanah yang memiliki populasi tinggi. Keenam isolat tersebut merupakan isolat yang dominan ditemukan dengan karakteristik koloni yang berbeda. Isolat jamur tanah yang dominan tersebut adalah TMa01, TMa02, TMa03, TMb02, TMb03, TMf01 (Tabel 3).

Jamur isolat TMa01 pada hari kedua membentuk koloni berwarna putih, selanjutnya pada hari ketiga mengalami sporulasi membentuk warna hijau tua. Isolat TMa01 memiliki permukaan koloni berstruktur kasar atau kering, bentuk koloni tidak beraturan, elevasi cembung, dan tepi bercuping. Jamur isolat $\mathrm{TMa} 02$, TMb02, dan TMb03, membentuk koloni bulat, dengan warna miselium hijau gelap, hijau muda, kuning emas, dan ungu yang mencolok (Gambar 1). Isolat TMa03 membentuk koloni putih kemudian berubah warna menjadi kuning dengan bintik-bintik menyerupai sklerotia di bagian permukaannya. Jamur isolat TMf01 pada hari keempat membentuk koloni bulat tipis berwarna putih, selanjutnya pada hari ketujuh mengalami sporulasi berwarna merah muda tidak beraturan. Permukaan koloni isolat TMf01 berstruktur haluslembut, bentuk koloni bulat, elevasi cembung, dan tepi menyeluruh (Gambar 1). 
Tabel 2. Populasi koloni isolat jamur tanah yang didapatkan dari tanah dengan perlakuan formulasi minyak mimba

\begin{tabular}{ccc}
\hline Nomor & Isolat jamur & Jumlah koloni (cfu/ml) \\
\hline 1 & TMa01 & $11 \times 10^{4}$ \\
2 & TMa02 & $19 \times 10^{4}$ \\
3 & TMa03 & $24 \times 10^{4}$ \\
4 & TMa04 & $1 \times 10^{4}$ \\
5 & TMb01 & $1 \times 10^{4}$ \\
6 & TMb02 & $12 \times 10^{4}$ \\
7 & TMb03 & $5 \times 10^{4}$ \\
8 & TMb04 & $1 \times 10^{4}$ \\
9 & TMb05 & $1 \times 10^{4}$ \\
10 & TMc01 & $1 \times 10^{4}$ \\
11 & TMc02 & $2 \times 10^{4}$ \\
12 & TMc03 & $3 \times 10^{4}$ \\
13 & TMc04 & $1 \times 10^{4}$ \\
14 & TMd01 & $1 \times 10^{4}$ \\
15 & TMd02 & $1 \times 10^{4}$ \\
16 & TMd03 & $2 \times 10^{4}$ \\
17 & TMd04 & $1 \times 10^{4}$ \\
18 & TMd05 & $2 \times 10^{4}$ \\
19 & TMf01 & $63 \times 10^{4}$ \\
20 & TMf02 & $4 \times 10^{4}$ \\
21 & TMf03 & $3 \times 10^{4}$ \\
\hline
\end{tabular}
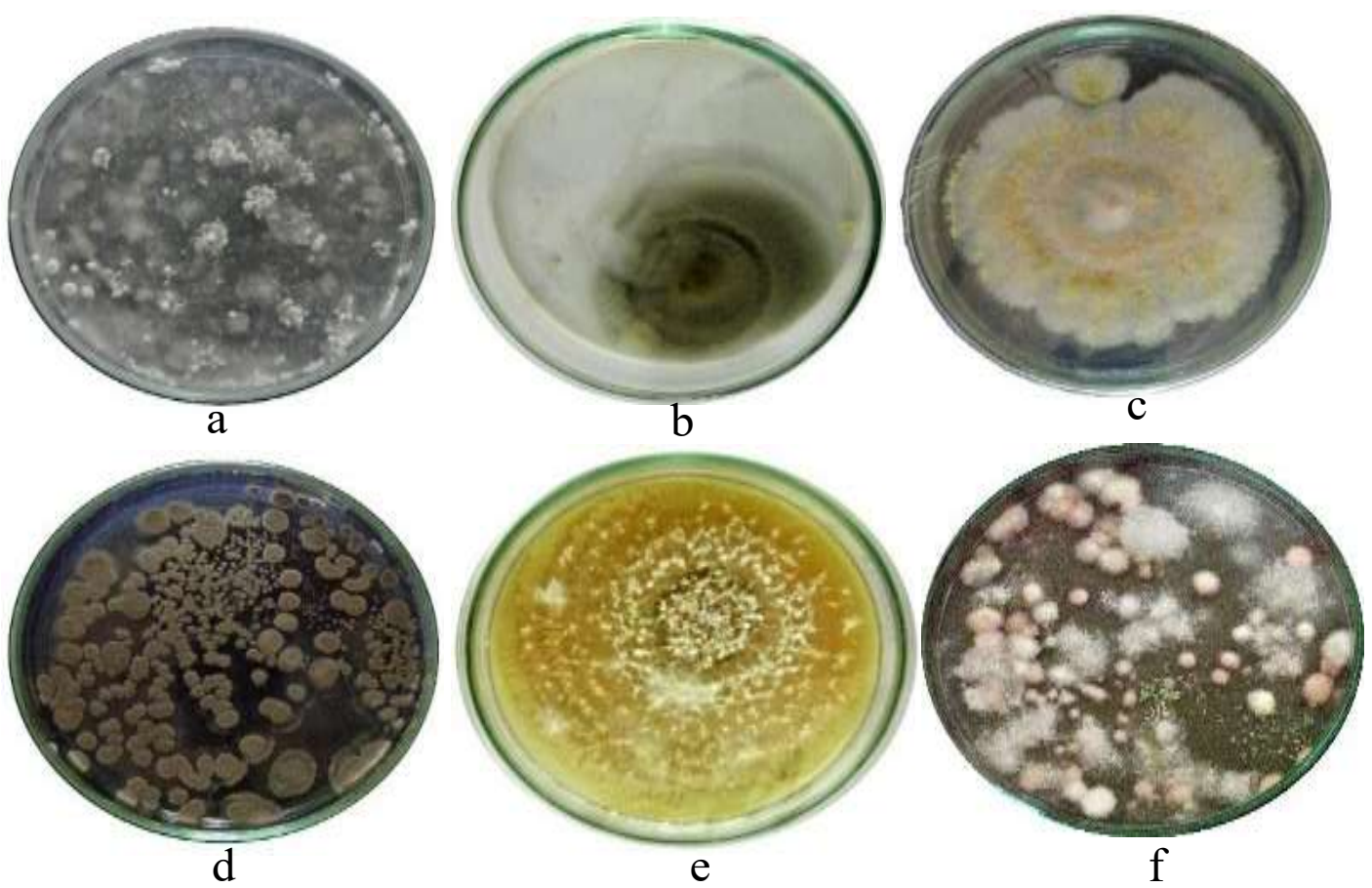

Gambar 1. Koloni isolat jamur tanah yang dominan hasil isolasi dari perlakuan formulasi minyak mimba (a. TMa01, b. TMa02, c. TMa03, d. TMb02, e. TMb03, f. TMf01) 
Tabel 3. Karakteristik jamur tanah yang dominan didapatkan dari isolasi tanah dengan perlakuan formulasi minyak mimba

\begin{tabular}{cccccc}
\hline \multirow{2}{*}{ Isolat } & \multicolumn{5}{c}{ Karakteristik koloni } \\
\cline { 2 - 5 } TMa01 & Bentuk & Elevasi & Warna & Tepi & Struktur \\
\cline { 2 - 5 } TMa02 & Bulat & Cembung & Hijau keputihan & Bercuping & Kasar \\
TMa03 & Tidak beraturan & Datar & Kuning & Menyeluruh & Kasar \\
TMb02 & Bulat & Datar & Hijau gelap & Menyeluruh & Kasar \\
TMb03 & Bulat & Datar & Hijau muda & Menyeluruh & Halus-licin \\
TMf01 & Bulat & Cembung & Ungu & Menyeluruh & Halus-lembut \\
\hline
\end{tabular}

\section{Pengaruh Formulasi Minyak Mimba terhadap Populasi Jamur Tanah}

Berdasarkan analisis statistik, perlakuan formulasi minyak mimba tidak berpengaruh terhadap populasi jamur tanah. Berdasarkan analisis statistik diketahui bahwa meningkatnya konsentrasi formulasi minyak mimba tidak menekan populasi jamur tanah dibandingkan dengan perlakuan kontrol pada taraf nyata 5\%. Apabila dilihat dari nilai rata-rata populasi jamur tanah, perlakuan formulasi minyak mimba dengan konsentrasi $2 \%$ memiliki populasi jamur tanah yang rendah dibandingkan kontrol dan perlakuan formulasi minyak mimba dengan konsentrasi $1 \%$, $1,25 \%, 1,50 \%$, dan $1,75 \%$ (Tabel 4). Perlakuan kontrol pada 3 mst menunjukkan populasi jamur tanah yang lebih rendah hingga akhir pengamatan dibandingkan perlakuan yang lain kecuali konsentrasi formulasi minyak mimba $1 \%$ (Tabel 4). Formulasi minyak mimba dengan beberapa perlakuan konsentrasi yang diberikan tidak bersifat fitotoksik terhadap tanaman cabai.

Populasi jamur tanah pada setiap pengamatan dari 3 mst hingga 9 mst dengan perlakuan berbagai konsentrasi formulasi minyak mimba menunjukkan bahwa populasi jamur tanah mengalami peningkatan kecuali kontrol. Hal tersebut diduga karena waktu paruh dari formulasi mimba yang cepat menyebabkan bahan aktif terurai. Mimba merupakan salah satu bahan pestisida nabati yang umumnya memiliki karakteristik mudah terdegradasi atau terurai secara cepat oleh beberapa faktor lingkungan (Bond et al., 2012). Beberapa faktor lingkungan yang membantu terjadinya proses degradasi atau penguraian tersebut adalah sinar matahari, udara dan kelembaban (Rusdy, 2009).

Tabel 4. Pengaruh formulasi minyak mimba terhadap populasi jamur tanah

\begin{tabular}{|c|c|c|c|c|}
\hline \multirow{2}{*}{ Perlakuan } & \multicolumn{3}{|c|}{ Populasi jamur tanah $(\mathrm{cfu} / \mathrm{mL})$ pada } & \multirow{2}{*}{$\begin{array}{l}\text { Rata-rata } \\
\text { (cfu/mL) }\end{array}$} \\
\hline & $3 \mathrm{mst}$ & $6 \mathrm{mst}$ & $9 \mathrm{mst}$ & \\
\hline Kontrol & $60000,0 \pm 17,32$ & $776666,7 \pm 606,65$ & $443333,33 \pm 400,4$ & 426666,67 \\
\hline Mimba $1 \%$ & $43333,3 \pm 49,32$ & $806666,7 \pm 90,18$ & $960000 \pm 726,9$ & 603333,3 \\
\hline Mimba $1,25 \%$ & $93333,3 \pm 35,11$ & $2323333,3 \pm 1703,53$ & $553333,33 \pm 270,9$ & 990000,0 \\
\hline Mimba $1,50 \%$ & $133333,3 \pm 75,05$ & $1476666,7 \pm 1734,94$ & $613333,33 \pm 310$ & 741111,1 \\
\hline Mimba $1,75 \%$ & $123333,3 \pm 75,71$ & $436666,7 \pm 197,31$ & $833333,33 \pm 185,8$ & 464444,4 \\
\hline Mimba $2,0 \%$ & $93333,3 \pm 56,86$ & $146666,7 \pm 195,02$ & $683333,33 \pm 198,9$ & 307777,78 \\
\hline
\end{tabular}

Keterangan: Nilai rata-rata \pm SD

Faktor lingkungan yang dapat mempengaruhi dampak formulasi minyak mimba terhadap perkembangan jamur tanah adalah suhu, $\mathrm{pH}$ tanah, dan kelembaban. Suhu harian, $\mathrm{pH}$ tanah, dan kelembaban selama penelitian berturut-turut berkisar antara $22-33,8^{\circ} \mathrm{C}, \quad 6,20-7,25$, dan $67-86 \%$. Berdasarkan data tersebut suhu, $\mathrm{pH}$ dan kelembaban di lingkungan selama penelitian ini mendukung pertumbuhan dan perkembangan jamur tanah, tetapi diduga dapat menyebabkan terdegradasinya bahan aktif formulasi minyak mimba. Menurut Rousk et al. (2009) pertumbuhan jamur meningkat pada $\mathrm{pH}$ tanah antara 4,5 sampai 8,3 . Kelembaban relatif pada $75 \%$ hingga $43 \%$ merupakan fase dimana jamur mulai terhambat pertumbuhannya (Tang et al., 2015). Berdasarkan data suhu harian, pH tanah, dan kelembaban tersebut, maka secara umum dapat dikatakan bahwa kondisi lingkungan selama penelitian cukup mendukung pertumbuhan dan perkembangan jamur tanah.

\section{Tingkat Penekanan Formulasi Minyak Mimba terhadap Jamur Tanah secara In Vitro}

Perlakuan beberapa konsentrasi formulasi minyak mimba tidak berpengaruh signifikan terhadap penekanan jamur tanah isolat TMa01 dan TMf0. Hasil pengamatan tingkat penekanan formulasi mimba 
menunjukkan bahwa penekanan terjadi pada hari pertama setelah perlakuan. Pada hari kedua dan seterusnya formulasi mimba tidak menekan pertumbuhan jamur tanah secara in vitro. Bahkan pada hari keempat diameter isolat jamur TMa01 telah memenuhi cawan petri. Pada hari pertama setelah inkubasi, formulasi mimba dengan konsentrasi $2 \%$ mempunyai aktivitas penekanan isolat TMf01 paling tinggi dibanding dengan konsentrasi yang lain (Tabel 5).

Tabel 5. Tingkat penekanan formulasi minyak mimba terhadap isolat jamur TMa01 dan TMf01 pada hari pertama setelah perlakuan

\begin{tabular}{lcc}
\hline \multirow{2}{*}{ Perlakuan } & \multicolumn{3}{c}{ Tingkat penekanan formula minyak mimba $(\%)$ terhadap isolat } \\
\cline { 2 - 3 } & TMa01 & TMf01 \\
\hline Kontrol & 0 & 0 \\
Mimba 1,0\% & $36,60 \pm 25,3$ & $42,19 \pm 16,3$ \\
Mimba 1,25\% & $32,63 \pm 26,7$ & $52,61 \pm 7,4$ \\
Mimba 1,50\% & $49,46 \pm 7,7$ & $51,28 \pm 9,7$ \\
Mimba 1,75\% & $49,81 \pm 28,4$ & $52,61 \pm 7,48$ \\
Mimba 2,0\% & $43,46 \pm 11$ & $56,65 \pm 29,9$ \\
\hline
\end{tabular}

Keterangan: nilai rata-rata, $\pm \mathrm{SD}$

Tingkat penekanan formulasi minyak mimba terhadap isolat jamur TMa01 berkisar antara 32,63 sampai 49,81\%. Tingkat penekanan formulasi minyak mimba terhadap isolat jamur TMf01 berkisar antara 23,28 sampai 56,65\%. Konsentrasi formulasi minyak mimba $1,75 \%$ paling tinggi dalam menekan isolat TMa01. Sementara itu, tiga konsentrasi formulasi minyak mimba yaitu $1,25 \%, 1,50 \%$, dan $2,0 \%$ dapat menekan isolat TMf01 dengan tingkat penekanan diatas 50\% (Tabel 5).

Penekanan pertumbuhan isolat jamur tanah oleh formulasi minyak mimba disebabkan senyawa bioaktif azadirachtin sebagai senyawa antifungi utama dalam tanaman mimba (Schumutterer, 1995). Selain kandungan bahan aktif azadiraktin, terpenoid lain seperti meliantriol, desactylimpin, quercetin, sitosterol, nimbin, nimbinin, nimbidin, nimbosterol, dan margisinin memberikan efek antimikroba (Bhatnagar \& McCormick, 1988). Ruskin (1993) melaporkan bahwa senyawa nimbin dan nimbidin yang terkandung dalam mimba mempunyai efek fungisidal yang tinggi dengan menghambat pertumbuhan miselium patogen. Senyawa quercetin dan $\beta$-sitosterol dari golongan flavonoid dari ekstrak daun mimba segar mempunyai efek antibakteri dan antijamur (Govindachari, 1998).

\section{Intensitas Penyakit Bercak Daun Cercospora pada Tanaman Cabai setelah Aplikasi Formulasi Minyak Mimba}

Penyakit bercak daun cercospora ditemukan di lahan pengamatan mulai umur tanaman cabai 4 minggu setelah pindah tanam. Gejala penyakit bercak daun cercospora berupa bercak berwarna coklat dengan warna putih keabuan di bagian tengah dan coklat gelap di bagian tepinya. Gejala penyakit bercak daun cercospora yang ditemukan di lahan penelitian disajikan pada Gambar 2.

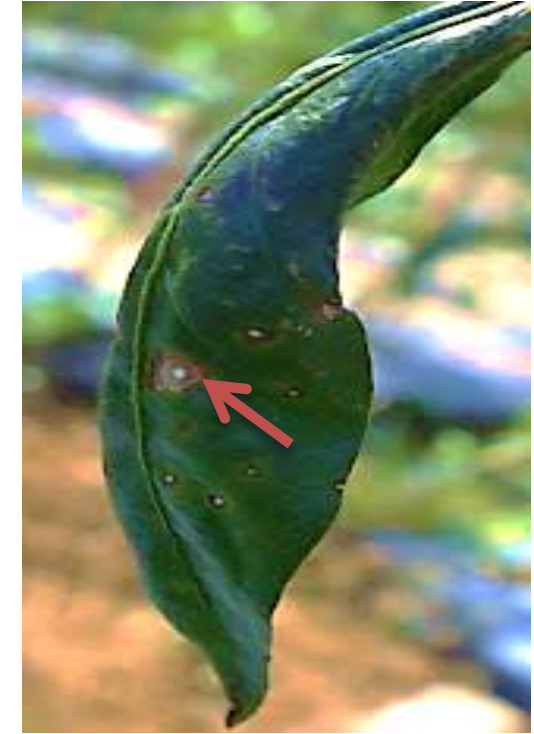

Gambar 2. Gejala bercak daun cercospora pada tanaman cabai di lahan

Hasil analisis statistik menunjukkan bahwa aplikasi berbagai konsentrasi formulasi minyak mimba pada tanaman cabai tidak berpengaruh terhadap keparahan penyakit bercak daun cercospora (Tabel 6). Hasil pengamatan intensitas penyakit bercak daun cercospora pada 6 mst maupun 9 mst dengan berbagai perlakuan konsentrasi formulasi minyak mimba menunjukkan tingkat keparahan bercak daun cercospora lebih rendah daripada kontrol (Tabel 6). Keparahan penyakit bercak daun cercospora yang diamati pada kontrol memiliki nilai tertinggi hingga 32,8\% (Tabel 6). Rata-rata keparahan penyakit terendah terjadi pada konsentrasi $2 \%$ (Tabel $6)$. 
Tabel 6. Keparahan penyakit bercak daun cercospora pada tanaman cabai dengan perlakuan formulasi minyak mimba

\begin{tabular}{lccc}
\hline \multirow{2}{*}{ Perlakuan } & \multicolumn{3}{c}{ Keparahan penyakit (\%) pada } \\
\cline { 2 - 4 } & $3 \mathrm{mst}$ & $6 \mathrm{mst}$ & $9 \mathrm{mst}$ \\
\hline Kontrol & $3,2 \pm 7,1$ & $16 \pm 10,1$ & $32,8 \pm 15,8$ \\
Mimba 1\% & $0,8 \pm 1,7$ & $12,8 \pm 5,2$ & $26,4 \pm 14,5$ \\
Mimba 1,25\% & $4 \pm 6,9$ & $11,2 \pm 3,3$ & $21,6 \pm 7,7$ \\
Mimba 1,50\% & $1,6 \pm 3,5$ & $14,4 \pm 5,3$ & $21,6 \pm 4,5$ \\
Mimba 1,75\% & $2,4 \pm 3,5$ & $8,8 \pm 3,3$ & $19,2 \pm 12,4$ \\
Mimba 2,0\% & $0 \pm 0$ & $10,4 \pm 3,3$ & $17,6 \pm 6$ \\
\hline
\end{tabular}

Keterangan: nilai rata-rata $\pm \mathrm{SD}$

Formula minyak mimba memberikan dampak pada penyakit bercak daun cercospora disebabkan oleh senyawa aktif yang terkandung dalam mimba yang berperan sebagai antijamur yaitu dari golongan terpenoid. Senyawa terpenoid merupakan salah satu senyawa metabolit sekunder yang memiliki aktivitas antimikroba. Pertumbuhan mikroorganisme seperti bakteri dan jamur dapat dihambat oleh senyawa tersebut dengan merusak dinding sel, merubah permeabilitas sel, merubah molekul protein dan asam nukleat, serta mengkoagulasi protoplasma (Pelczar dan Chan, 1988). Rusdy (2009) melaporkan bahwa semakin tinggi konsentrasi ekstrak mimba yang digunakan maka semakin rendah tingkat kerusakan yang ditimbulkan oleh patogen. Formula minyak mimba yang digunakan dalam penelitian ini telah dilaporkan mampu menekan intensitas penyakit embun tepung pada tanaman kedelai (Meliansyah $e t$ al., 2016).

Ekstrak mimba dengan bahan aktif salanin dan nimbin merupakan bahan sistemik, pestisida sistemik dapat diserap jaringan daun dengan daya kerja translaminar (Djojosumarto, 2000). Pestisida berdaya kerja translaminar mempunyai daya penetrasi ke dalam jaringan daun. Dengan demikian tingkat kerusakan daun yang disebabkan oleh patogen dipengaruhi oleh konsentrasi mimba yang digunakan.

\section{KESIMPULAN}

Formulasi minyak mimba tidak berpengaruh terhadap populasi jamur tanah dan penyakit bercak daun cercospora pada tanaman cabai. Akan tetapi, formulasi minyak mimba dengan konsentrasi $2 \%$ mampu menekan jamur tanah isolat TMf01 sebesar 56,65\%. Formulasi minyak mimba konsentrasi 2,0\% mampu menekan intensitas penyakit bercak daun cercospora sebesar $46,34 \%$.

\section{DAFTAR PUSTAKA}

Barus, I. 2016. Pengaruh Formula Insektisida Mimba (Azadirachta Indica Juss) Terhadap Populasi Beberapa Serangga Hama dan Arthopoda Musuh Alami Pada Tanaman Kedelai (Glycine
Max L. Menril). UNPAD. Sumedang. Makalah yang dipresentasikan.

Bhatnagar, D., and SP McCormick. 1988. The inhibitory effect of neem (Azadirachta indica) leaf extracts on aflatoxin synthesis in Aspergillus parasiticus. J. Am. Oil Chem.' Soc. 65(7): 1166-1168.

Bond, C., K Buhl, and D Stone. 2012. Neem Oil General Fact Sheet. National Pesticide Information Center, Oregon State University Extension Services. http://npic.orst.edu/ factsheets/neemgen.html.

Djojosumarto, P. 2000. Teknik Aplikasi Pestisida Pertanian. Penerbit Kanisius Yogyakarta. 212 Hlm.

Govindachari, TR, G Gobalakrishnan, G Suresh. 1998. Isolation of various Azadiraktins from neem oil by preparative high performance liquid chromatography. J. Liq. Chromatogr. \& Rel. Technol. 19:1729-1733.

Locke, JC. 1990. Activity of extracted neem seed oil against fungal plant pathogens. Locke, J.C., editor; and R.H. Lawson, editor. Neem's Potential in Pest Management Programs, Proceedings of the USDA Neem Workshop United States Department of Agriculture, Agricultural Research Service, ARS-86, pp.136.

Meliansyah, R, D Dono, LTripuspasari. 2016. The effect of neem formulation 50 EC in suppressing powdery mildew diseases on soybean. Sumedang: Fakultas Pertanian Universitas Padjadjaran. Makalah yang dipresentasikan

Natarajan, V, VP Venugopal, T Menon. 2003. Effect of Azadirachta Indica on the growth pattern of dermatophytes. Ind. J. Med. Microbiol., 21: 98-101.

Pelczar, MJ, dan ECS Chan. 2005. Dasar-Dasar Mikrobiologi, Jilid 1. Penerjemah: Ratna Sri Hadioetomo, Teja Imas, S. Sutarmi Tjitrosomo, dan Sri Lestari Angka, UI Press, Jakarta, 551 hlm. 
Rousk, J, PC Brookes, E Baath. 2009. Contrasting soil $\mathrm{pH}$ effects on fungal and bacterial growth suggest functional redundancy in carbon mineralization. Appl. Environ. Microbiol. 75(6): 1589-1596. doi:10.1128/AEM.02775-08

Rusdy, A. 2009. Efektivitas ekstrak nimba dalam pengendalian ulat grayak (Spodoptera litura F.) pada tanaman selada. J. Floratek 4: 41-54.

Ruskin. 1993. Pestisida Nabati: Ramuan dan Aplikasi. Penebar Swadaya. Jakarta. $80 \mathrm{hlm}$.

Schmutterer, H. 1995. The neem tree: source of unique natural products for integrated pest management, medicine, industry and other purposes. VCH, Weinheim, Thomson, W.T. Agricultural Chemicals. Book I: Insecticides. Thomson Publications, Fresno, CA. 696 p.

Sharvelle, E.G. 1979. Plant Disease Control. AVI Publishing Company. Inc. Wesport, Connecticut.
Tang, W, TH Kuehn, MF Simcik. 2015. Effects of Temperature, Humidity and Air Flow on Fungal Growth Rate on Loaded Ventilation Filters. J Occup Environ Hyg. 12(8):525-37. doi: 10.1080/15459624.2015.1019076.

Thomas, B, JD Murphy, GB Murray. 2016. Encyclopedia of Applied Plant Sciences, 2nd Edition. Academic press: HRI Wellesbourne, UK.

Unterstenhofer, G. 1976. The Basic Principles of crop Protection Field Trial. Bayer Plflanttensshutz.

Wang J, J Li, J Cao, W Jiang. 2010. Antifungal activities of neem (Azadirachta indica) see kernel extracts on postharvest diseases in fruits. African Journal of Microbiology Research. 4(11):1100-1104. Available online http://www.academicjournals.org/ajmr.

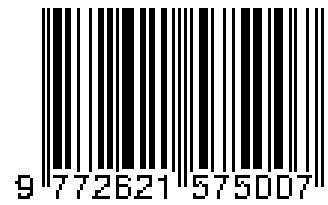

